\title{
DAYTON PEACE ACCORDS TWO DECADES AFTER: CONSTITUTIONAL SETTLEMENT AS SERIOUS OBSTACLE TO THE CREATION OF A FUNCTIONAL STATE
}

\author{
Zarije Seizovic \\ University of Sarajevo \\ Goran Simic \\ International University of Sarajevo
}

\begin{abstract}
Twenty-one years after entering into force of the General Framework AgreementforPeace in Bosniaand Herzegovina (theDayton Agreement), it seems that the political situation in Bosnia and Herzegovina has not significantly changed. The basic achievements of the Dayton Agreement, such as stopping the war and country's democratization and institution building processes are evident, however the agreement failed to create a politically stable functional state and the united nation accepted by all its citizens. On the contrary, the agreement significantly contributed to the creation of divided society (and political community) composed of three 'constituent peoples' and others. Neither social nor political community stood the test of time. The country could not meet the requirements and standards set by the European Union, especially the constitutional reform that is claimed to be the precondition to other reforms. Then, despite agreement's significant accomplishments in the field of human rights protection it generated State political structure based on the principle of the three constituent peoples' exclusive ethnic representation, all at the expense of rights of individual.
\end{abstract}

Keywords: Dayton Peace Accords; Bosnia and Herzegovina; Human Rights; Discrimination

\section{Introduction}

In face of legal, political and ethnic challenged the state of Bosnia and Herzegovina has been under the political integration slogan, undergoing artificial institutional reanimation under the International Community's patronage. From the constitutional and legal point of views, theoretically and in practice, the Dayton Peace Agreement has 
contributed towards the foundation of a sort of John Lackland's country. However, as constitutionally, legally and politically affirmed and fashioned union DPA gave the birth to the questionable state consisting of two Entities: 'republic' and a 'federation.' The union, consisting of these two Entities, is short of clear conception of a sovereign (unitary) state, a state with clear system of governance or at the end clear republican or federal state-system. Therefore, the end outcome of the DPA was the creation of a post-modern semi state without any former precedents in the history, which within the Balkan's geopolitical and geo-cultural melting pot depends strongly on the foreign political patrons offered as the only viable modus vivendi. The state has (was), after the forced by-pass installation in Dayton, revitalized, re-established itself as a state and re-contextualized as above all and odd union based on a principle 'one state - two entities - three constituent peoples', the principle that had been playing a key role in a long-term and constant disintegrative processes and tendencies within Bosnia and Herzegovina.

The rise of nationalism and ethno-nationalism as a result of the new world order especially faced by the East-European communist totalitarian regimes, became obstacles for the genuine democratization process of former communist countries and their societies, including Bosnia and Herzegovina. The DPA and its Constitution within it had institutionalized the ethnic nationalism. The Preamble of the Constitution of Bosnia and Herzegovina prevents the state to create the legal environment in which the power-sharing system would be organized within the civil society, whilst at the same time it favor's the ethno-nationalism and collective rights of the ethno-national-religious communities at the expense of an individual or the citizen (Anex 4, Dayton Peace Agreement). Therefore Mujkic (2008) was rightly arguing that

the public arena in Bosnia and Herzegovina is a testing ground for collectivism that enjoys absolute freedom, subsuming the individual, to the utmost possible extent, under its abstract categories. The democracy of the three ethno-religious groups is thus no other than a democracy of oligarchies, groups of authoritarian members or ethnic groups engaged in shaping ethnic, collectivist narratives; and such a democracy is meaningless (p. 39).

\section{Constitutional Settlement and Non-effective Institution-Building}

The Constitution of Bosnia and Herzegovina defines Bosniacs, Croats and Serbs as 'constituent peoples', while 'others' and 'citizens' are 
barely mentioned. The anachronistic 'constituent peoples' notion, by recognizing collective rights of ethnic groups (nations), represents rather obvious violating of The Convention for the Protection of Human Rights and Fundamental Freedoms, since the guiding idea of the protection of human rights was aimed at the citizen as an individual not as a member of a social/religious/ethnic/national group. The very Constitution of Bosnia and Herzegovina in Article II, Paragraph 4 introduces the principle of the non-discrimination clause, at the same time directly breaching both very Article and Article 14 of the Convention (Prohibition of Discrimination). Ergo, the existing concept of 'constituent peoples' as the state-building nations and the relation of it towards the constitutional and legal position of 'Others' constitutes discrimination par excellence. Such constitution represents the institutional discrimination of several hundreds of thousands of citizens who do not belong to 'the chosen ones', including those who opted to exercise their 'not to belong to' legitimate right. Therefore, the Constitution as main outcome of DPA incorporates the discriminatory concept that recognizes different legal/ political/constitutional dimensions of Bosnian citizens, endorsed by the judgement of the European Court of Human Rights in the case Sejdić and Finci vs. Bosnia and Herzegovina. The 'national veto' principle, the principle of protecting the 'national interests' respectively, provides ethno-nationalistic elites across state administration almost unlimited possibilities to block the enactment of law or regulation, whenever they consider it as a breach of 'national interests' of one of constituent peoples.

The legal vacuum has been often filled in by Office of the High Representative for Bosnia and Herzegovina (OHR), which according to Annex 10 of the DPA (Civilian implementation) has the ultimate power. Acting in this regard discouraged the consolidation of democratic political processes in Bosnia and Herzegovina. Without any doubt, that action turned to be unavoidable tool for making the sufficient, although important step forward to efficient institution building process. However, the question is "Could the institution building be imposed?"

The national homogenization process is still alert and active obstacle on the path of the economic and political reintegration of the country and the society, with active role in the processes of decomposing the newly emerging state institutions. It appears that, as long as the ethnonational identity concept is the only (or the most potent) source of citizens' identification, and the 'constituent peoples' the constitutional category, 
the state of Bosnia and Herzegovina will continue to be essentially dysfunctional in many aspects of a well-organized state. Certainly after upcoming general elections and the establishment of new government, it is inevitable to undertake a true and authentic political, constitutional and judicial review of the constitutional provisions (the entity constitutions included as well), for the purpose of the promotion of civil and the negation of national/ethnic aspects of the constitution. It seems important to emphasize that reaching this objective is emerging responsibility of both local and international political actors and leaders because there is an international and legal obligation to harmonize Bosnian legislation with European standards and, as well as, its Constitution, as described in judgment of the European Court of Human Rights. If these changes do not materialize, Bosnia and Herzegovina will risk remaining at margins of the Euro-Atlantic integrations. Certainly, any state on the path towards the European Union, including Bosnia and Herzegovina, must develop the single and functional state, well-organized government, rule of law and protection of individual rights and freedoms.

\section{Shortcomings of the Dayton Peace Agreement}

Instead of reinforcing 1000 years old statehood of Bosnia and Herzegovina, Agreement has accepted results of bloody campaign of war crimes and ethnic cleansing that took place in the period from 1992 to 1995. Instead of bringing justice to the victims and society, Agreement had frozen division of Bosnia and Herzegovina and legalized widespread discrimination of its citizens. The fighting in Bosnia and Herzegovina ended in 1995 not because of internal peace settlement and consensus but because of an intervention and pressure from the great powers. Instead of establishing the justice for victims and society, reconciliation and overcoming common suffering and destruction of lives and property, nationalist leaders of Bosnia and Herzegovina just continued the war by using different means. In that sense, it is justified to say that today's Bosnia and Herzegovina is not living in peace, but rather in state of "frozen conflict" or "absence of armed conflict." In this regard, the last twenty years had passed in ethnic struggle of reinforcing divisions, by means of different methods including politics, media, and education.

Based on the notion of the Dayton Agreement and its implications, according to Seizovic (2014) Bosnia and Herzegovina could be considered failed state. He explained that 
a failed state is perceived as a state that is not being successful at some of the fundamental preconditions and responsibilities of a sovereign government. There is no universal meaning, description and/or definition of such state. However, a state meeting certain criteria would be understood as a failed state. Criteria are but are not limited to the following: (1) Loss of control of its territory, or loss of the monopoly on the legitimate use of physical force within its territory; (2) Decline of legitimate power that collective decision-making is being bestowed into; (3) Incapability to provide public services and (4) Failure to enter into an interaction with other states as a full capacity member of the international community. In addition to that, general characteristics of a failing state would be, inter alia, weak and ineffective central government as well as extensive corruption and criminality. Bosnia and Herzegovina, in many segments of its functioning meets almost all the above listed criteria, but is very often described as democratic state, state being under reform/s and/or having modern European features within the realm of public administration, judiciary, law enforcement, etc. All things considered, one may say that on the surface, the Bosnia and Herzegovina has vastly modern European face but, is, actually a disguised failed state par excellence (p. 5).

Bosnia and Herzegovina is the state where there is so-called institutionalized and legalized discrimination. As a consequence of the war in Bosnia and Herzegovina (1992-1995) and unwillingly accepted peace, Dayton Agreement removed from Constitution of the Republic of Bosnia and Herzegovina the possibility for all citizens of to identify themselves as Bosnians and Herzegovinians (e.g. Germans in Germany), or just citizens of Bosnia and Herzegovina. in contrast newly invented categories were founded such as: "constituent peoples" (Bosniacs, Croats and Serbs) as well as "Others" (those non-constituent). Although Agreement claimed that it promoted the human rights, it introduced fundamental discrimination of all citizens of Bosnia and Herzegovina.

The first illustrative example is related to the election of a member of Presidency of Bosnia and Herzegovina (body consists of three members). The candidate is a citizen but at the same time he/she is the member of one of the three constituent peoples since Constitution provides that Presidency of Bosnia and Herzegovina is composed of one member of each constituent people. Discrimination doesn't stop even there. Serbian member of Presidency can be elected only from the entity of Republic of Srpska territory, while Bosniac and Croat members can be elected only from the citizens residing in the entity of Federation of Bosnia and Herzegovina. 
The second illustrative example is the House of Peoples of Parliamentary Assembly of Bosnia and Herzegovina, which consists of 15 members, 5 from each constituent people. Serbs are elected in the entity of Republic of Srpska while Bosniacs and Croats are elected from the territory of the entity of Federation of Bosnia and Herzegovina. Consequently, discriminations is very much visible not only in the above-mentioned examples but across all spheres of cultural, educational, administrative and institutional aspects of life. Ironically, rights and freedoms set forth in the European Convention for the Protection of Human Rights and Fundamental Freedoms and its Protocols are applied directly in Bosnia and Herzegovina, having priority over all other law (according to Constitution of Bosnia and Herzegovina).

Obviously, not only so-called "Others" are discriminated but also socalled "constituent peoples", depending on which entity within Bosnia and Herzegovina citizen resides in. It was more than clear that The Bosniakhood, Croatianhood and Serbianhood cannot be limited to one or just some parts of territory. Presumption of being Bosniac, Croat or Serb does not automatically mean an association with specific part of the territory where (or used to) live members of that particular ethnicity (Seizovic, 2014 , p. 23). Bosniac, Croat or Serb affiliation occurs independently of the territory where members of that particularly ethnicity live.

Denying status of constituent peoples to Bosniacs and Croats in the entity of Republika Srpska and Serbs in the entity of Federation of Bosnia and Herzegovina are both in discord with the Constitution and have no historical justification, as it is well known that Bosnia has always been a multi-ethnic society sui generis and paradigm of "unity and tolerance". The same pattern is applicable to "Others" on whole territory of Bosnia and Herzegovina.

\section{Lenses of the Constitutional Court of Bosnia and Herzegovina}

In order to correct constitutional discrimination, the Constitutional Court of Bosnia and Herzegovina in July 2000 requested both entities the Federation of Bosnia and Herzegovina and the Republic of Srpska to amend their constitutions in order to ensure full equality of the three "constituent peoples" throughout the state territory. Therefore, this decision partially eliminated Dayton's discriminatory elements and put an end of the idea of recognizing the right of the Bosnian Croats to establish their small statelike entity, as it required both entities to become and remain multinational. Some opponents were considering that this decision is in violation of the 
Dayton Agreement while those advocating idea of a single state considered the decision a breakthrough towards further institutional improvements upon the existing Dayton political architecture that, to their opinion, had to undergo constitutional changes. Ademovic (2010) was furthermore criticizing this decision by asserting that even though the decision denoted significant step forward in recognizing the same constitutional position of all constituent peoples in every part of territory of the state, it did nothing in favor of improving the position of non-constituent population of $\mathrm{BiH}$. With or without the decision, the constitutional position of the nonconstituent peoples remained the same: they were still non-constituent throughout the country (pp. 215-140).

\section{Discrimination and the European Court of Human Rights}

In the case Sejdic and Finci v. Bosnia and Herzegovina ${ }^{1}$, the European Court of Human Rights had established that Constitution of Bosnia and Herzegovina contains discriminatory provisions. As such, the Judgment constitutes legal and political disgrace as well as strong strike upon its international position and renommé of Bosnia and Herzegovina. In any member-state of the Council of Europe, such judgment of the highest authority for human rights would entail mobilization of all essential efforts and powers to amend the Constitution in order to make it conform it to the said judgment (Seizovic, 2014, p. 43). However, in Bosnia and Herzegovina, local politicians did nothing as to implement the European Court of Human Rights decision. Moreover

[t] he negotiations related to future organization of the State are being held in the restaurants throughout Bosnia and Herzegovina. In a rather arrogant and unacceptable manner, political talks are transposed from Parliamentary benches to restaurants, asserting ugly connotation of a tavern-like discourse in administering the state (Ibid., p. 46)

Such unbearable indolence of ethno-national political elites ${ }^{2}$ as well

1) European Court of Human Rights, Grand Chamber, Case of Sejdić and Finci v. Bosnia and Herzegovina, Applications nos. 27996/06 and 34836/06, Judgment, Strasbourg, 22 December 2009. The same judgment ECtHR rendered in two similar cases: Azra Zornic vs. Bosnia and Herzegovina, Application no. 3681/06, Judgment, Strasbourg, 15 July 2014 and Ilijaz Pilav v. Bosnia and Herzegovina,(Application no. 41939/07), Judgment, Strasbourg, 9 June 2016.

2) „Ethnopolitics is somewhat weird term. The meaning of word ethnos implies prepolitical category of the people referring to its blood origin, heritage, tradition. [...] The ethnos is best described as kinship, Mujkic, Asim, We, the Citizens of Ethnopolis, 
as complete absence of any effects as to implementation of judgment had created perception that Bosnia and Herzegovina is positioned against its citizens Sejdić and Finci and as well as a common view that all citizens are discriminated against. The decision had confirmed that the Constitution contains a discriminatory concept, which makes the very discrimination institutionalized. ${ }^{3}$ Therefore, "the political practice in Bosnia can be rightly described as the democracy of ethnic oligarchies, not as democracy of citizens" (Mujkic, 2008, p. 18). Besides, Seizovic (2000) is explicit in declaring that

It is obvious that "[n]ational homogenization will still remain the main obstacle to political and economic reintegration of the [...] society and will be playing significant role in continuing disintegration processes throughout the country while national (ethnic) identity will very likely be almost sole identification model for the [...] citizens" (p. 12).

The ethno-national affiliation as cornerstone of the political system in Bosnia and Herzegovina constitutes serious drawback to firm institutional building that is inevitable for any serious future EU member-state. Actual demographic structure of the country does not match either pre-war percentages ${ }^{4}$ or the Dayton electoral system, which does not treat properly the number of citizens that do not consider themselves as members of constituent people, or do not want to identify themselves at all. Citizens of civic orientation are considered to be the fourth constituent people. ${ }^{5}$

Human Rights Centre of the University of Sarajevo, Sarajevo, 2008, p. 21. „In Bosnian case Ethnopolitics is very similar to Religious nationalism". Bosnian ethnic groups („constituent peoples“) are basically formed along the religious lines as the only "striking" difference between the communities. In fact, there is a little to their ethnicity besides their „religiousness“, Mujkic, Asim, We, the Citizens of Ethnopolis, Human Rights Centre of the University of Sarajevo, Sarajevo, 2008, p. 23.

3) In December 2009, European Court of Human Rights has declared State Constitution and Election law discriminating against Roma and Jewish population in $\mathrm{BiH}$. See: Human Rights Watch, Second Class Citizens: Discrimination against Roma, Jews, and Other National Minorities in Bosnia and Herzegovina (2012), p. 2. The judgement of the European Court has not been implemented almost seven years after it had been taken.

4) Statistics show that the 1991 census national break-down was the following: 43,7\% Bosniacs, $31,3 \%$ Serbs, $17,3 \%$ Croats and $7,7 \%$ of Others.

5) International Crisis Group (2012) Bosnia's Gordian Knot: Constitutional Reform, Policy Briefing Europe $\mathrm{N}^{\circ} 68$ Sarajevo/Istanbul/Brussels, p. 13. There are opinions that the term „Others“, „due to dominant ethnic pattern [...] refers to ethnic minorities: Roma, Jewish, Ukrainians, Czech and others that live in $\mathrm{BiH}^{\text {“ }}$ - see: Asim Mujkić, „Others - the Fourth constitutive element of strategy of democratic transformation?”, 
In this regard Seizovic (2014) explains that

ethnical, cultural, traditional, habitual as well as other components of complicated $\mathrm{BiH}$ social milieu is composed of sophisticated net of Bosnian concord of diversity, so territorial principle taken as a base to form an opinion on somebody's ethnic affiliation has no either theoretical or practical rationalization. Thereby any idea and/or theory of "ethno-cantonisation" or any other "ethno-regionalisation", notwithstanding if it comes from "outside" or "inside", is absolutely incompatible with multiethnic concept of the $\mathrm{BiH}$ society and entails latent threat to survival of the State of $\mathrm{BiH}$. Cantonisation, of course, might be concept of internal institutional structure of the multi-ethnic state under the condition that it is a civilized state in which any form of diversity cannot be ground for human rights violation whatsoever. On the other side cantonisation and/or regionalisation based on natural and geographical distinctiveness, as model of "de-entitetisation" of $\mathrm{BiH}$ seems to be the reasonable and logical constitutional solution for internal state organization of $\mathrm{BiH}$ (pp. 23-24).

\section{Conclusion}

The above explained and analyzed constitutional predicaments clearly indicate that Bosnia and Herzegovina, and international community along with it, will have to make important decision. There are fears that if the practice of institutionalized discrimination and legal division of the country continue it will inevitably lead to the emergence of the new conflict. Therefore, as a solution besides proper constitutional changes an attention should be directed towards social-economic, educational and cultural developments that will assure non-recurrence of violence in the future and provide sustainable economic development. Only in that way, future of Bosnia and Herzegovina can be bright and peaceful.

Accordingly, it is necessary to undertake political and constitutional restoration of the human rights protection system in Bosnia and

in Abazović, Dino et al (ed..), Place and role of „Others“ in the Constitution of Bosnia and Herzegovina and Future Constitutional Settlements for Bosnia and Herzegovina, Social research Institute - Faculty of Political Sciences of the University of Sarajevo, 2010 , p. 80.). It has to be stressed that civic principle of organizing state and power as well as advocating „effective“ state model definitely are not inherently neutral institutional positions. Those features are being inwrought into political conflict of dominant political encampments in which the Bosniac side, at least formally, enjoys support to its political position. On the other side, Bosnian Serbs and Bosnian Croats in any such manoeuvre, which they consider rhetoric, see potential undermining of their political elite position, but also undermining the multi-ethnic principle. 
Herzegovina through systematic review of all provisions of the Constitution aiming to affirm the civil as opposed to national basis for enjoyment of individual rights. It is indispensable to emphasize that it is not discretionary power of the state of Bosnia and Herzegovina but its obligation to its citizens and its international obligation to harmonize its legislation with European standards and create non-discriminatory legal framework and environment for its citizens. In that regard, a non-discrimination clause, provided for in Article II (4) of the Constitution states that

The enjoyment of the rights and freedoms provided for in this Article or in the international agreements listed in Annex I to [...] Constitution shall be secured to all persons in Bosnia and Herzegovina without discrimination on any ground such as sex, race, color, language, religion, political or other opinion, national or social origin, association with a national minority, property, birth or other status. ${ }^{6}$

The above citation clearly indicates that the "principle of constituent peoples" containing the exclusive connotation of "non-constituent" for none members of these groups, per se, constitutes discriminatory treatment against those who are "non-constituent", and others, simply depriving them of the status of citizens independent of their group characteristics. On the contrary Bosnia and Herzegovina must ensure that all citizens enjoy equal rights and freedoms in every single part of the Bosnian territory, no matter what nationality they belong to.

\section{References}

European Convention of Human Rights. (1950).

European Court of Human Rights. (2014). Azra Zornic vs. Bosnia and Herzegovina, Application no. 3681/06, Judgment, Strasbourg.

European Court of Human Rights. (2009). Case of Sejdić and Finci v. Bosnia and Herzegovina, Applications nos. 27996/06 and 34836/06, Judgment, Strasbourg.

European Court of Human Rights. (2016). Ilijaz Pilavv. Bosnia and Herzegovina, (Application no. 41939/07), Judgment, Strasbourg.

Human Rights Watch. (2012). Second Class Citizens: Discrimination Against Roma, Jews, and Other National Minorities in Bosnia and Herzegovina.

6) The Dayton Peace Accords, General Framework Agreement for Peace in Bosnia and Herzegovina, Paris, 14 December 1995, Office of Public Communication, Bureau of Public Affairs, U.S. Department of State. 
International Crisis Group. (2012). Bosnia’s Gordian Knot: Constitutional Reform, Policy Briefing Europe N68 Sarajevo/Istanbul/Brussels.

Mujkic, Asim. (2008). We, the Citizens of Ethnopolis. Sarajevo:_Human Rights Center of the University of Sarajevo.

Place and role of „Others“ in the Constitution of Bosnia and Herzegovina and Future Constitutional Settlements for Bosnia and Herzegovina (Mjesto i uloga „Ostalih“ u Ustavu Bosne i Hercegovine i budućim ustavnim rješenjima za Bosnu i Hercegovinu). (2010). Sarajevo: Centar za ljudska prava Univerziteta u Sarajevu.

Seizovic, Zarije. (2000). "Human Rights Protection in Bosnia and Herzegovina, within the Framework of the Dayton Peace Accords with Special View to Non-Discrimination Policy", essay written in the course of Summer School "Post-Communist transition and the European Integration Processes", organized by Instituto per l'Europa Centro-Orientale e Balcanica International Network Europe and the Balkans and Italian Ministry of Interior in Cervia, Italy.

Seizović, Zarije. (2014). Bosnia Nowadays - A Disguised Failed State. Sarajevo: Dobra knjiga.

Seizovic, Zarije. (2014). Constituent Peoples and Constitutional Changes, 2nd updated edition. Sarajevo: Dobra knjiga.

The Dayton Peace Accords, General Framework Agreement for Peace in Bosnia and Herzegovina, Paris, 14 December 1995, Office of Public Communication, Bureau of Public Affairs, U.S. Department of State. 